Ius Matrimoniale 32 (2021) $\mathrm{nr} 1$

ISSN 1429-3803; e-ISSN 2353-8120

DOI: http://doi.org/10.21697/im.2021.32.1.04
Artykuł jest udostępniany na zasadach licencji Creative Commons (CC BY-ND 4.0 Międzynarodowe) https://creativecommons.org/licenses/by-nd/4.0/deed.pl

open 2 access (cc) (i)

\title{
Parafilia a nieważność małżeństwa kanonicznego w wybranych publikacjach
}

\section{Paraphilia and canonical marriage nullity in selected publications}

\author{
Kinga Szymańska \\ Sąd Metropolitalny Warszawski \\ ORCID: 0000-0001-9000-3448 \\ e-mail: kinga.szymanska@interia.pl
}

Streszczenie: Z przeprowadzonych analiz wynika, że przedstawiciele doktryny prawa kanonicznego traktują parafilie jako zagrożenie dla małżeństwa i rodziny, traktując je jako przykład dezintegracji psychoseksualnej danej osoby. Zdaniem kanonistów omawiane odstępstwa mogą uniemożliwić zawarcie ważnego przymierza małżeńskiego ze względu na niezdolność parafilika do podjęcia i wypełnienia istotnych obowiązków małżeńskich, takich jak: ustanowienie małżeńskiej wspólnoty życia, ustanowienie więzi międzyosobowej między małżonkami, utrzymanie stałego, wiernego, wzajemnego i długotrwałego związku w celu utrzymania wspólnoty heteroseksualnej, urodzenia i wychowania potomstwa lub urzeczywistnienia współżycia intymnego humano modo. Jednak sama obecność parafilii nie przesądza o niezdolności osoby do zawarcia małżeństwa. W tym zakresie kanoniści zalecają uwzględnienie stopnia nasilenia danej anomalii, odwołując się tym samym do badań Urbano Navarrete i włoskiego psychiatry Gianfrancesco Zuanazziego. Jednocześnie należy unikać pochopnej oceny wagi danej parafilii i uważnie oceniać każdą przedstawioną sprawę, biorąc pod uwagę rodzaj odchylenia, jego cechy, a także osobowość kontrahenta.

Słowa kluczowe: parafilia, zaburzenia parafiliczne, kanoniczne prawo małżeńskie, nieważność małżeństwa, proces o stwierdzenie nieważności małżeństwa

Abstract: The conducted analyzes show that the representatives of the doctrine of canon law perceive paraphilias as a threat to marriage and family, considering them as an example of psychosexual disintegration of a given person. According to the canonists, the discussed deviations may prevent the conclusion of a valid marriage covenant due to the paraphiliac's incapacity to undertake and fulfil important marital duties such as: establishing a conjugal marital community of life, to establish an interpersonal relationship between spouses, to maintain a permanent, faithful, mutual and long-lasting relationship, to maintain heterosexual community, to give birth and raise offspring or to have intimate life realised humano modo. However, the mere presence of paraphilia does not prejudge the fact that a person is incapable of entering into marriage. In this regard, the canonists recommend 
taking into account the degree of intensity of a given anomaly, thus referring to the studies of Urbano Navarrete and Italian psychiatrist Gianfrancesco Zuanazzi. At the same time, it is necessary to avoid rash judgement as to the severity of the paraphilia in question, and to carefully evaluate each case submitted, taking into account the type of deviation, its features and also the personality of the contracting party.

Keywords: paraphilia, paraphilic disorders, canonical marriage law, marriage nullity, marriage proces

Treść: Wstęp. 1. Problem parafilii w publikacjach przed promulgacją Kodeksu prawa kanonicznego z 1983 roku. 2. Problem parafilii w publikacjach po promulgacji Kodeksu prawa kanonicznego z 1983 roku. 2.1. Destrukcyjne oddziaływanie parafilii na funkcjonowanie małżeństwa 2.2. Trudności klasyfikacyjne. 2.3. Wpływ parafilii na nieważność małżeństwa kanonicznego. Zakończenie.

\section{Wstęp}

Parafilie stanowią przedmiot zainteresowania wielu dziedzin wiedzy, w tym i kanonistyki. Okazuje się, iż sygnalizowany problem w kanonistyce nie jest nowy, gdyż przez niektórych autorów opracowań, a także audytorów rotalnych, był już podejmowany przed promulgacją Kodeksu prawa kanonicznego z 1983 roku. Ten fakt stał się bodźcem do podjęcia namysłu nad destrukcyjnym wpływem tego zaburzenia na funkcjonowanie małżeństwa kanonicznego, w publikacjach poświęconych temu zagadnieniu.

\section{Problem parafilii w publikacjach przed promulgacją Kodeksu prawa kanonicznego z 1983 roku}

Jak nadmieniono, kwestia wpływu parafilii na zgodę małżeńską została podjęta jeszcze w czasie obowiązywania Kodeksu Pio-Benedyktyńskiego, przez Charlesa J. Ritty w opublikowanym w 1964 roku artykule „Invalidity of marriage by reason of sexual anomalies”. Jak wiadomo, w Kodeksie z 1917 roku nie ujęto jeszcze normy w znaczeniu dzisiejszego kan. 1095, n. 1-3 KPK/83 określającej wpływ niezdolności

1 Por. C.J. Ritty, Invalidity of marriage by reason of sexual anomalies, The Catholic Lawyer 10 (1964) nr 2, s. 90-108. 
konsensualnej kontrahenta na zgodę małżeńską. Niemniej jednak autor wspomnianego opracowania wykazał, iż wątek parafilii pojawiał się w orzecznictwie Roty Rzymskiej w kontekście kilku tytułów: impotencji psychicznej, wykluczenia dobra potomstwa oraz braku wystarczającego rozeznania oceniającego. Oprócz tego spostrzegł, że wówczas w trybunałach kościelnych wzrastała liczba spraw, w których istotną rolę odgrywały anomalie seksualne, $w$ tym również parafilie 2 . Omawiając ten problem skorzystał ze statystyki opracowanej przez Johna R. Cavanagha ${ }^{3}$, który wymienił następujące formy zaburzeń: voyeuryzm, ekshibicjonizm, transewestytyzm, fetyszyzm, sadyzm, masochizm, nekrofilię, kazirodztwo, gwałt, trolizm, prostytucję, sodomię, bestialstwo, pedofilię, nimfomanię oraz homoseksualizm ${ }^{4}$.

Niestety kanonista nie podjął się omówienia poszczególnych parafilii w przedmiocie ich wpływu na ważność umowy małżeńskiej, gdyż organiczył się wyłącznie do podjęcia kwestii nimfomanii ${ }^{5}$ oraz homoseksualizmu ${ }^{6}$, uzasadniając swój wybór ilością spraw występujących w orzecznictwie Roty Rzymskiej ${ }^{7}$. Na marginesie należy

2 Por. TAmże, s. 90.

3 Por. J.R. Cavanagh, Sexual Anomalies and the Law, The Catholic Lawyer, 9 (1963), s. 4-31.

4 Por. C.J. Ritty, Invalidity of marriage..., s. 92.

5 Szerzej na temat ewolucji orzecznictwa Roty Rzymskiej w kwestii nimfomanii: W. Góralski, Niezdolność do wypełnienia obowiązków małżeńskich jako tytut nieważności małżeństwa, Studia Płockie 9 (1981), s. 203-221.

6 Szerzej na temat homoseksualizmu: F.R. ANZAR GiL, Homosexualismo, transexualismo y matrimonio (1965-1984), w: Curso de derecho matrimonial y procesal canónico para profesionales del foro, 7 (1986), s. 281-343; F.R. ANZAR GIL, Trastornos sexsuales y de la identidal sexual: orientaciones jurisprudenciales canónicas, w: Curso de derecho matrimonial y procesal canónico para profesionales del foro, 13 (1997), s. 231-276; G. ERLEBACH, Tożsamość seksualna a nieważność związku matżeńskiego według najnowszej jurysprudencji rotalnej (1983-1994). Zarys tematyczny, w: B.W. Zubert (red.), Tożsamość seksualna nupturientów a zdolność do zgody małżeńskiej, Opole 1998, s. 105-160; G. ZuanazzI, Psicologia e psichiatria nelle cause matrimoniali canoniche, Città del Vaticano 2012.

7 Warto zauważyć, że zagadnienie homoseksualizmu pojawiało się w orzecznictwie Roty Rzymskiej już w 1929 roku. Szerzej na ten temat: T.J. Green, Homosexuality and the Validity of Marriage - The Developing Jurisprudence, The 
wspomnieć, że zgodnie z obowiązującymi wówczas klasyfikacjami ICD oraz DSM zaburzenia te były zaliczane do dewiacji seksualnych ${ }^{8}$.

Wracając do przerwanego wątku, za istotną należy uznać konstatację Ritty'ego utrzymującego, iż w związku z pojawianiem się coraz większej ilości różnych przejawów patologii osobowości w sferze seksualnej, obowiązujący od 1917 roku Kodeks prawa kanonicznego nie dostarczał skutecznych narzędzi do orzekania w przypadku pojawienia się parafilii. Należy dodać, iż kanonista swe stanowisko poparł twierdzeniem zaczerpniętym z artykułu „Welchen Einfluss hat die Homosexulität auf die Ehe?”, autorstwa G. Oesterle", który snując rozważania na temat wpływu parafilii w postaci homoseksualizmu na ważność małżeństwa, zwrócił uwagę, iż w tym wypadku problem tkwi nie tyle w braku zgody kontrahenta obciążonego taką anomalią, ale w samym jego prawie do zawarcia małżeństwa. Stąd też, jego zdaniem, sądy kościelne w prowadzeniu spraw o stwierdzenie nieważności małżeństwa winny skupić uwagę nie tyle na symulacji całkowitej lub częściowej, ale na niezdolności nupturienta do wypełnienia przyjętego zobowiązania ${ }^{10}$.

Należy zauważyć, iż z powyższych względów w dalszej części swego wywodu Ritty odrzucił ówczesnie dominującą koncepcję psychopaty seksualnego postrzeganego w kategoriach osoby normalnej we wszystkich obszarach ludzkiego postępowania, poza sferą seksualną. Przechodząc do szczegółowego uzasadnienia przyjętego

Linacre Quarterly 43 (1976) nr 3, s. 196-207; A. STANkiEwicz, Homoseksualizm jako przyczyna nieważności małżeństwa według najnowszej jurysprudencji rotalnej (1956-1976), Prawo Kanoniczne 22 (1976) nr 3-4, s. 179-198; A. GoŁĘBıowsKA, Homoseksualizm jako przyczyna nieważności małżeństwa według orzecznictwa Roty Rzymskiej i trybunałów kościelnych, Seminare 32 (2012), s. 31-47.

8 Por. Diagnostic and Statistical Manual of Mental Disorders, Washington DC 1968, s. 44: R.B. Krueger, G.M. Reed, M.B. First, A. Marais, E. Kismodi, P. Briken, Proposals for Paraphilic Disorders in the International Classification of Diseases and Related Health Problems, Eleventh Revision (ICD-11), Archives of Sexual Behavior 46 (2017) nr 5, s. 1531.

9 Por. G. Oesterle, Welchen Einfluss hat die Homosexulität auf die Ehe?, Österreichisches Archiv für Kirchenrecht 12 (1961), s. 305-337.

10 Por. C.J. Ritty, Invalidity of marriage..., s. 101-105. 
stanowiska, amerykański kanonista argumentował, iż osoby cierpiące na anomalie seksualne (sexual anomalies) bądź defekty psychopatyczne (psychopathic defects) nie powinny zawierać małżeństwa. Jeśli natomiast zawarłyby je, wówczas z aspektu procesowego każdy przypadek należałoby rozpatrywać indywidualnie, gdyż w jego opinii, odpowiedzialność za dokonane czyny, w tym również zdolność do zawarcia ważnego małżeństwa, jest uzależniona od stopnia intensywności zaburzenia. Uzasadniając swój pogląd, Ritty zwrócił uwagę, iż spoglądając na anomalie seksualne z pryzmatu okoliczności sprawy, należałoby w pierwszym rzędzie wziąć pod uwagę pewne wyznaczniki, mianowicie czy konkretne zachowanie było powtarzalne, a także czy miało obsesyjny i kompulsywny charakter? W jego opinii odpowiedzialność za czyny w głównej mierze jest zależna od podstawowego zaburzenia (basic disorder), a nie od przestępstwa seksualnego (sexual offense) czy stopnia kompulsywności związanej z chorobą ${ }^{11}$.

W literaturze przedmiotu wskazuje się, że wraz z rozwojem nauk medycznych ewaulowało również stanowisko doktryny kanonistycznej w kwestii parafilii. Jak zauważa Wojciech Góralski, niejako nową jakość wyznaczył wyrok c. Lefebvre z 2 grudnia 1967 roku, w którym turnus rotalny powołując się na progres nauk medycznych, orzekając w kwestii anomalii psychoseksualnej za jaką uważany był wówczas homoseksualizm, powołał się na zasadę św. Tomasza z Akwinu, w myśl której nikt nie może w sposób ważny zaciągać zobowiązań, których nie jest w stanie wypełnić12 ${ }^{12}$ Omawiając wspomniany wyrok, Antoni Stankiewicz zauważył, iż w tym przypadku przedmiotowa anomalia stanowiła przyczynę braku należnego rozeznania (defectus discretionis iudicii), gdyż ze względu na stan nerwicowy i stały konflikt ze swym „ego” znosiła wolność wyboru ${ }^{13}$.

11 Por. TAmżE, s. 92.

12 Por. W. Gór alski, Niezdolność do wypełnienia obowiązków małżeńskich..., s. 211.

13 Por. A. Stankiewicz, Homoseksualizm jako przyczyna nieważności małżństwa..., s. 182. 
Doktryna Vaticanum II (1962-1965) oraz wspomniany wyrok sprawiły, że w latach 70. XX wieku wzrosła liczba spraw, w których przedmiotem były zaburzenia o podłożu psychoseksualnym, takie jak nimfomania czy homoseksualizm ${ }^{14}$. W tym zakresie za istotne z punktu naszych rozważań należy uznać orzeczenie c. Raad z 13 listopada 1979 roku, w którym, na co zwraca uwagę Paul Wesemann, sędziowie rotalni wskazali, że osoba dotknięta zaburzeniem psychoseksualnym była traktowana jako niezdolna do podjęcia i wypełniania obowiązków małżeńskich ${ }^{15}$.

\section{Problem parafilii w publikacjach po promulgacji Kodeksu prawa kanonicznego z 1983 roku}

Badając publikacje wydane po ogłoszeniu Kodeksu prawa kanonicznego z 1983 roku, należałoby wyróżnić następujące wątki tematyczne: problem wpływu parafilii na fukcjonowanie małżeństwa, zagadnienie trudności klasyfikacyjnych oraz kwestię wpływu parafilii na nieważność małżeństwa kanonicznego

\subsection{Destrukcyjne oddziaływanie parafilii na fukcjonowanie małżeństwa}

Na temat wpływu parafilii na fukcjonowanie małżeństwa i rodziny wypowiedział się Tomasz Gwoździewicz ${ }^{16}$. Przy tym należy zauważyć, co jest godne podkreślenia i uwagi, iż obiektem jego zainteresowania stało się nie tylko destrukcyjne oddziaływanie parafilii specyficznych, ale również parafilii niespecyficznych, takich jak: anilingus, bukkake, bondage czy kink, które choć w społeczeństwie zazwyczaj traktowane są jako zabawy erotyczne, to jednak z punktu

\footnotetext{
14 Por. G. Leszczyński, Proces kształtowania się kanonu 1095 Kodeksu Prawa Kanonicznego, Łódzkie Studia Teologiczne 9 (2000), s. 339.

15 Por. P. Wesemann, Psychiczna niezdolność do małżeństwa jako problem sądownictwa kościelnego, Kościół i Prawo 3 (1984), s. 79-110.

16 Por. T. GwoźDZIEwICZ, Wpływ parafilii na małżeństwo i rodzinę-aspekt moralny, Teologia i Moralność 15 (2020) nr 1, s. 109-120.
} 
widzenia moralności chrześcijańskiej pojmuje się je jako dewiacje ${ }^{17}$. Opierając się na podejściu do tego zagadnienia Joachima Piegsy, ${ }^{18}$ Gwoździewicz postrzega destrukcyjny wpływ interesującego nas zaburzenia na ludzką osobowość w kategoriach depersonalizacji, która następuje według określonych stopni. Proces ten opisał następująco: „heteroseksualność - dojrzały partner płci przeciwnej, pedofilia - niedojrzały partner, homoseksualizm - partner tej samej płci, ekshibicjonizm - partner jako statysta, fetyszyzm - namiastka partnera, nekrofilia - nieżyjący partner, koprofilia - namiastka partnera, mord na tle seksualnym - partner zniszczony"19. Konkludując, autor opracowania wskazał na następujące elementy parafilii, które wpływają negatywnie na wspólnotę małżeńską: obsesyjność w praktykach dewiacyjnych, gwałty małżeńskie, niewłaściwe nastawienie do małżonka (np. ekshibicjonizm), zdrady, a także negatywne postawy wobec potomstwa w postaci pedofilii bądź kazirodztwa ${ }^{20}$.

\subsection{Trudności klasyfikacyjne}

Zasadniczym bodźcem do pogłębienia namysłu nad kwestią parafilii było wprowadzenie w 1983 roku nowego Kodeksu prawa kanonicznego, w którym znalazł się kan. 1095 KPK/83 odnoszący się do niezdolności konsensualnej. Według Ricardo Mediny istotnym problemem kanonistów doby Kodeksu Jana Pawła II był problem niejednoznacznych stanowisk uczonych w kwestii etiopatogenezy parafilii, a także problem chorób współistniejących z tą anomalią, do których zaliczył: schizofrenię oraz zaburzenia endokrynologiczne skutkujące utratą kontroli nad sobą ${ }^{21}$. Odwołując się do dzieła „Nuevas normas

\footnotetext{
17 Por. TAMżE, s. 111-112.

18 Por. J. Piegsa, Człowiek - istota moralna, t. 3, Opole 2000.

19 Por. TAmżE, s. 279.

20 Por. T. GwoźDzIEw ICz, Wpływ parafilii na małżéstwo i rodzinę..., s. 111-118.

21 Por. R.D. Medina, Imputabilidad, eximentes, atenuantes y agravantes en los delitos sexuales de clerigos con menores, Anuario Argentino de Derecho Canonico 19 (2013), s. 105-151.
} 
sobre la nulidad de la ordenación sacerdotal. Texto y comentario"22, Medina zwrócił uwagę, iż w związku z takim stanem nie można abstrahować od faktu, że schizofrenia oraz inne towarzyszące parafilii zaburzenia mogą poważnie wpływać na funkcjonowanie rozumu, ograniczając tym samym zdolność kontrahenta do krytycznego osądu oraz logicznego rozumowania ${ }^{23}$. Według argentyńskiego kanonisty opisane problemy potęgują się ze względu na to, że zaburzenia, o których mowa, z reguły mają charakter trwały, gdyż zazwyczaj podjęte wysiłki terapeutyczne nie przynoszą oczekiwanych rezultatów w postaci całkowitego wyleczenia ${ }^{24}$.

$\mathrm{W}$ ten nurt organicznie wpisują się również rozważania Josè A. Fuentesa, wskazującego, iż w prowadzeniu spraw o stwierdzenie nieważności małżeństwa istotne jest odróżnienie parafilii od innych zaburzeń. W artykule „Desviaciones de la sexualidad. Parafilias y transsexualismo en las causas de nulidad matrimonial canonica" wskazuje, iż parafilie mogą pojawiać się jako objaw w chorobie psychicznej, przykładem czego może być obsesyjna nerwica w zaburzeniach osobowości. Taki stan doprowadził kanonistę do sformułowania tezy, że nie należy mylić parafilii z chorobą psychiczną, bądź wspomnianym zaburzeniem osobowości. Stąd też w takiej sytuacji, według hiszpańskiego autora, należy rozeznać stan kontrahenta, w sensie czy został on doktknięty chorobą psychiczną, czy jednocześnie współwystępowały parafilia oraz choroba psychiczna. Tłumacząc głębiej tę kwestię Fuentes zauważył, iż zwykle choroby psychiczne stanowią zaburzenie w rozwoju ludzkiej osobowości; parafilie natomiast, jak to określił, wydają się trwałą raną, która pojawia się wyłącznie

22 Por. J. SAN José Prisco, Nuevas normas sobre la nulidad de la ordenación sacerdotal. Texto y comentario, Revista Española de Derecho Canónico 60 (2003), s. 136-137.

${ }^{23}$ Por. R. Medina, Imputabilidad, eximentes, atenuantes..., s. 119.

${ }^{24}$ Por. TAmże. 
w wymiarze seksualnym ${ }^{25}$. Victor E. von Gebsattel ${ }^{26}$ wyraził pogląd, iż parafiliczna osobowość występuje wówczas, gdy jakość i intensywność zboczonych czynów prowadzi do degradacji godności zarówno własnej osoby, jak i współpartnera ${ }^{27}$.

\subsection{Wpływ parafilii na nieważność małżeństwa kanonicznego}

Bez względu na to, czy parafilii towarzyszą inne choroby lub zaburzenia, zdaniem Mediny, choć parafilik, wie co robi, i zdaje sobie sprawę z konsekwencji swych czynów, to jednak nie jest on całkowicie wolną osobą, a zaburzenie, którym został dotknięty, z czasem może przekształcić się w chorobę psychiczną ${ }^{28}$. Tłumacząc swe stanowisko, zwrócił uwagę, że dewiacjom seksualnym zazwyczaj towarzyszy jakiś komponet nerwicy obsesyjnej lub kompulsywnej, który sprawia, że popęd wywiera determinujący wpływ na zdolności intelektualne i wolicjonalne podmiotu ${ }^{29}$. Samo występowanie parafilii, jego zdaniem nie przesądza jednak o fakcie niezdolności danej osoby do zawarcia małżeństwa. W ocenie istotny jest bowiem stopień nasilenia danej anomalii, na co uwagę zwracają zarówno Medina, jak i Fuentes. Pierwszy z nich wyróżnił dwie kategorie parafili: parafilie pierwotne, u podłoża których leżą zaburzenia psychiczne lub seksualne; w tym wypadku zachowania jednostki są głęboko zinternacjonalizowane. Druga kategoria to parafilie epizodyczne przejawiające się w zachowaniach sporadycznych, nienawykowych. Zazwyczaj są one następstwem nadużywania alkoholu, narkotyków

\footnotetext{
25 Por. J.A. Fuentes, Desviaciones de la sexualidad. Parafilias y transsexualismo en las causas de nulidad matrimonial canonica, Ius Canonicum 53 (2013) nr 106, s. 671 .

26 Por. V.E. von Gebsattel, Prolegomena einer medizinischen Antropologíe, Berlin - Göttingen - Heidelberg 1954, s. 180.

27 Por. J.A. Fuentes, Desviaciones de la sexualidad..., s. 664.

28 Por. R. Medina, Imputabilidad, eximentes, atenuantes..., s. 119.

29 Por. TAMŻE, s. 121.
} 
bądź nadpobudliwości seksualnej. W takich przypadkach $\mathrm{z}$ reguły osobowość nie jest poważnie zaburzona ${ }^{30}$.

Funetes z kolei w swych rozważaniach nawiązał do osiągnięć znanego włoskiego psychiatry Gianfrancesco Zuanazziego, który rozróżnił pomiędzy parafilią strukturalną oraz parafilią indcydentalną. Pierwszą uznał za konstytutywne zaburzenie osobowości, poważnie zagrażające interpersonalnym relacjom małżeńskim; drugie natomiast, na co wskazał, przejawiają się w incydentalnych fantazjach seksualnych, które niekoniecznie muszą destrukcyjnie wpływać na seksualne relacje małżonków ${ }^{31}$.

Odnosząc się do tych analiz, należy spostrzec, iż ukazane wywody nie były w kanonistyce czymś nowym. Są one koherentne z opinią wyrażoną w 1997 roku przez Urbano Navarrete, który rozważając kwestię niezdolności konsensualnej transwestyty, podkreślił z całym naciskiem, iż w ocenie stanu faktycznego istotny jest stopień intensywności tej anomalii. Stał na stanowisku, iż w sytuacji, gdy instynkty będące jej źródłem zostałyby opanowane, wówczas nie można postrzegać tego zaburzenia w kategoriach przyczyny niezdolności; jeśli zaś zaburzenie to miałoby charakter nieprzezwyciężalny, habitualnie wpływając na anormalny sposób zachowania nupturienta, wtedy taki stan mógłby generować, jego zdaniem, poważną niezdolność podmiotu do życia w małżeństwie, szczególnie w sferze seksualnej $^{32}$.

Należy zauważyć, iż w przeciwieństwie do Mediny, Fuentes ${ }^{33}$ w swych rozważaniach nie poprzestał jedynie na ukazaniu typologii; zajął się bowiem również kwestią wpływu zaburzeń seksualnych na fukcjonowanie małżeństwa i rodziny. Hiszpański kanonista podkreślił, iż dysfunkcje oraz dewiacje seksualne (disfunciones y desviaciones

\footnotetext{
30 Por. TAMŻe, s. 127.

31 Por. G. Zuanazzi, Psicología e psichiatria nelle cause matrimoniali canoniche, Roma 2006, s. 196.

32 Por. U. Navarrete, Transsexualismus et ordo canonicus, Periodica 86 (1997), s. 112 .

33 Por. J.A. Fuentes, Desviaciones de la sexualidad..., s. 655-690.
} 
sexuales) mogą destruktywnie oddziaływać na relacje interpresonalne w małżeństwie, szczególnie na współżycie intymne podjęte na sposób ludzki (humano modo) ${ }^{34}$. W jego opinii w efekcie zagrożone są: małżeńska wspólnota całego życia, dobro małżonków oraz skierowanie na potomstwo ${ }^{35}$. Stąd też, według autora publikacji, nie można wykluczyć nieważności małżeństwa z takich wad zgody małżeńskiej jak: wykluczenie augustyńskich trzech dóbr małżeńskich: dobra wiary, sakramentu oraz potomstwa (kan. $1101 \$ 2 \mathrm{KPK} / 83$ ), błąd faktyczny (kan. 1097 \$1-2 KPK/83), podstęp (kan. 1098 KPK/83), a także co jest najbardziej prawdopodobne - z niezdolności konsensualnej, o której mowa w kan. 1095 KPK/83. Poza tym, zdaniem Fuentesa, skutkiem dewiacji seksualnych może być też przeszkoda impotencji (kan. 1084 KPK/83); w niektórych sytuacjach małżeństwo może również zostać niedopełnione (kan. $1142 \mathrm{KPK} / 83)^{36}$.

Szczególnym obiektem zainteresowania kanonisty stała się korelacja zachodząca między parafilią a niezdolnością konsensualną. Zasygnalizowany problem poddał on analizie w pryzmacie numeru 2 i 3 kanonu 1095 KPK/83. Wyraził pogląd, iż tytuł kan. 1095 n. 2 KPK/83 należałoby aplikować, gdy zmianom psychicznym parafilii towarzyszy choroba psychiczna; w sytuacji natomiast gdy wystąpiłby jej brak, wówczas należałoby odnieść się do kan. 1095 n. 3 KPK/83 ${ }^{37}$. Zdaniem Profesora Universytetu w Nawarze mając na względzie intensywność popędu parafilicznego, a także biorąc pod uwagę fakt, że parafilik z reguły nie dąży do nawiązania z drugą osobą relacji wzajemnego oddania się i jej akceptacji, zwykle osoby takie nie

\footnotetext{
34 Por. TAMżE, s. 656-657.

35 Por. TAmże, s. 657.

36 Por. TAMżE.

37 Por. J.A. Fuentes, Desviaciones de la sexualidad..., s. 657: „En lo que se refiere a la incapacidad consensual, de entrada debemos advertir que esas alteraciones, si no van acompañadas de otra enfermedad psíquica, difícilmente comprometen la capacidad de discreción de juicio (c. 1095, 2). Sin embargo, con frecuencia, comprometen la capacidad de asumir las obligaciones esenciales del matrimonio (c. 1095, 3)".
} 
mają na celu zawarcia związku małżeńskiego. Wyjaśniając tę kwestię dopowiedział, iż zwykle jego dążenia są przeciwne prawdziwemu małżeństwu ${ }^{38}$.

Zagadnieniem wpływu parafilii na niezdolność do zawarcia małżeństwa zajęli się również polscy kanoniści. Józef Krzywda w artykule „Irracjonalność legalizacji związków homoseksualnych wobec jedynej i niepowtarzalnej wartości i roli małżeństwa i rodziny” wyartykułował tezę, iż dotknięci tą anomalią, w akcie płciowym godzą oni w dar życia; w takiej sytuacji więc współżycie seksualne małżonków nie jest wynikiem prawdziwej komplementarności uczuciowej i płciowej $^{39}$. Jan Cymbała z kolei badając wyroki rotalne z lat 1983-1992 ferowane z tytułu określonego w kan. 1095 n. 3 KPK/83 zauważył, iż osoby z zaburzeniami psychoseksualnymi z reguły nie są zdolne do podjęcia i wypełniania istotnych obowiązków małżeńskich ${ }^{40}$. W ten nurt wpisuje się również stanowisko Janusza Gręźlikowskiego, który w opracowaniu „Stwierdzenie nieważności małżeństwa w kościele katolickim - teoria i praktyka” podkreślił, iż zaburzenia psychoseksualne uniemożliwiają stworzenie wspólnoty małżeńskiej i realizację obowiązków małżeńskich w przedmiocie dobra małżonków oraz zrodzenia i wychowania potomstwa ${ }^{41}$. Również Ryszard Sztychmiler opowiedział się za uznaniem nie tylko sadyzmu, ale i nimfomanii oraz transseksualizmu za przyczyny natury psychicznej niezdolności, w rozumieniu kan. $1095 \mathrm{KPK} / 83^{42}$. Katalog ten poszerza o fetyszyzm

\footnotetext{
38 Por. TAMŻE, s. 672.
}

39 Por. J. KRZYwDA, Irracjonalność legalizacji związków homoseksualnych wobec jedynej i niepowtarzalnej wartości i roli małżeństwa i rodziny, Analecta Cracoviensia 44 (2012), s. 297.

40 Por. J. СумваєA, Istotne obowiązki małżeńskie i przyczyny niezdolności do ich podjęcia w wyrokach Roty Rzymskiej lat 1983-1992 wydanych na podstawie kan. 1095 nr 3 Kodeksu Prawa Kanonicznego, opublikowanych w „Decisiones”, Olsztyn 2002, s. 105.

41 Por. J. GręźLIKowski, Stwierdzenie nieważności małżeństwa w kościele katolickim - teoria i praktyka, Sympozjum (2010) nr 1, s. 82.

42 Por. R. SzTychmiler, Problem określenia istotnych obowiązków małżńskich, Ius Matrimoniale 7 (1996) nr 6/1, s. 70; R. SzTychmiLer, Istotne obowiq̨zki małżeńskie 
i inne parafilie kanonistka, psycholog i biegła sądowa Emilia Zyskowska, wyjaśniając, że osoby z zaburzeniami psychoseksualnymi nie są w stanie przekazać drugiej stronie przedmiotu konsensusu małżeńskiego w sferze seksualnej w opcji wyłączności ${ }^{43}$. Podobne poglądy wyrazili Mirosław Czapla ${ }^{44}$ oraz Bartosz Nowakowski ${ }^{45}$.

\section{Zakończenie}

Z przeprowadzonych analiz wynika, że przedstawiciele doktryny prawa kanonicznego upatrują poważnych zagrożeń dla małżeństwa i rodziny w parafiliach, postrzegając je w kategoriach dezintegracji psychoseksualnej ludzkiej osobowości. Zdaniem kanonistów parafilie będące dewiacjami mogą uniemożliwić zawarcie ważnego przymierza małżeńskiego, ze względu na niezdolność parafilika do podjęcia i wypełniania istotnych obowiązków małżeńskich (kan. $1095 \mathrm{KPK} / 83$ ), takich jak: utworzenie małżeńskiej wspólnoty życia, nawiązanie relacji międzyosobowej między małżonkami, utrzymanie relacji trwałej, wiernej, wzajemnej i dozgonnej, utrzymywanie wspólnoty heteroseksualnej, zrodzenie i wychowanie potomstwa czy pożycie intymne realizowane humano modo ${ }^{46}$. Autorzy większości prezentowanych publikacji stoją na stanowisku, iż samo wytępowanie parafilii nie przesądza jednak jednoznacznie o fakcie niezdolności nupturienta

w Kodeksie Prawa Kanonicznego z 1983 roku, Roczniki Nauk Prawnych 7 (1997), s. 131.

43 Por. E. Zyskowska, Rola biegłego psychiatry i psychologa w kanonicznym procesie o stwierdzenie nieważności małżeństwa na przykładzie kan. 1095 KPK, Kwartalnik Naukowy Fides et Ratio 28 (2016) nr 4, s. 306.

44 Por. M. Czapla, Charakterystyka prawna niezdolności psychicznej do przyjęcia istotnych obowiązków małżeńskich służących jedności i prokreacji (kan. 1095, n. 3 KPK), Ius Matrimoniale 13 (2002), s. 45-65.

45 Por. B. Nowa Kowski, Transwestytyzm a zdolność osoby do zawarcia małżeństwa, Łódzkie Studia Teologiczne 28 (2019) nr 3, s. 171-182.

46 Szerzej na temat obowiązków małżeńskich: R. SzTychmiler, Obowiązki małżeńskie: istotne i nieistotne, Ius Matrimoniale 9 (1998) nr 3, s. 115-134; W. GóR ALski, Istotne obowiązki małżeńskie w świetle orzecznictwa Roty Rzymskiej: zarys problematyki, Prawo Kanoniczne 52 (2009) nr 3-4, s. 225. 
do zawarcia małżeństwa. Stąd też zwracają uwagę, aby w orzekaniu w sprawach małżeńskich uwzględnić stopień nasilenia danej anomalii. Z drugiej strony podkreślają, iż należy wystrzegać się pochopnego osądu co do ciężkości parafilii, dlatego stoją na stanowisku, iż ostrożnie należy oceniać każdy przedłożony przypadek uwzględniając rodzaj dewiacji, jej cechy, a także osobowość kontrahenta.

\section{References}

\section{Źródła systematyczne}

\section{Prawo kanoniczne}

Codex Iuris Canonici auctoritate Joannis Pauli PP. II promulgatus, 25.01.1983, AAS 75 (1983), pars II, s. 1-317.

Codex Iuris Canonici Pii X Maximi iussu digestus Benediicti Papae XV auctoritatae promulgatus, 25.01.1917, AAS 9 (1917), pars II, s. 1-593.

\section{Opracowania}

Anzar Gil F.R., Homosexualismo, transexualismo y matrimonio (1965-1984), w: Curso de derecho matrimonial y procesal canónico para profesionales del foro, 7 (1986), s. 281-343.

Anzar Gil F.R., Trastornos sexsuales y de la identidal sexual: orientaciones jurisprudenciales canónicas, w: Curso de derecho matrimonial y procesal canónico para profesionales del foro, 13 (1997), s. 231-276.

Cavanagh J.R., Sexual Anomalies and the Law, The Catholic Lawyer, 9 (1963), s. 4-31.

Сумваєа J., Istotne obowiązki małżeńskie i przyczyny niezdolności do ich podjęcia w wyrokach Roty Rzymskiej lat 1983-1992 wydanych na podstawie kan. $1095 \mathrm{nr}$ 3 Kodeksu Prawa Kanonicznego, opublikowanych w „Decisiones”, Olsztyn 2002.

Czapla M., Charakterystyka prawna niezdolności psychicznej do przyjęcia istotnych obowiązków małżeńskich służących jedności i prokreacji (kan. 1095, n. 3 KPK), Ius Matrimoniale 13 (2002), s. 45-65.

ERLEBACH G., Tożsamość seksualna a nieważność związu małżeńskiego według najnowszej jurysprudencji rotalnej (1983-1994). Zarys tematyczny, w: B.W. ZUBERT (red.), Tożsamość seksualna nupturientów a zdolność do zgody małżeńskiej, Opole 1998, s. 105-160.

Fuentes J.A., Desviaciones de la sexualidad. Parafilias y transsexualismo en las causas de nulidad matrimonial canonica, Ius Canonicum 53 (2013), s. 655-690.

Gebsattel von V.E., Prolegomena einer medizinischen Antropologíe, Berlin - Göttingen - Heidelberg 1954. 
GoŁęBiowska A., Homoseksualizm jako przyczyna nieważności małżeństwa według orzecznictwa Roty Rzymskiej i trybunałów kościelnych, Seminare 32 (2012), s. 31-47.

GóR ALSKI W., Istotne obowiązki matżeńskie w świetle orzecznictwa Roty Rzymskiej: zarys problematyki, Prawo Kanoniczne 52 (2009) nr 3-4, s. 215-228.

Góralski W., Niezdolność do wypełnienia obowiązków małżńskich jako tytut nieważności małżeństwa, Studia Płockie 9 (1981), s. 203-221.

Green T.J., Homosexuality and the Validity of Marriage - The Developing Jurisprudence, The Linacre Quarterly 43 (1976) nr 3, s. 196-207.

GręźLIKowsKi J., Stwierdzenie nieważności małżeństwa w kościele katolickim teoria i praktyka, Sympozjum (2010) nr 1, s. 75-102.

GwoźDzIEwICz T., Wpływ parafilii na małżeństwo i rodzinę-aspekt moralny, Teologia i Moralność 15 (2020) nr 1, s. 109-120.

KRZYWDA J., Irracjonalność legalizacji związków homoseksualnych wobec jedynej $i$ niepowtarzalnej wartości i roli małżeństwa i rodziny, Analecta Cracoviensia 44 (2012), s. 297-306.

Leszczyński G., Proces kształtowania się kanonu 1095 Kodeksu Prawa Kanonicznego, Łódzkie Studia Teologiczne 9 (2000), s. 337-345.

Medina R.D., Imputabilidad, eximentes, atenuantes y agravantes en los delitos sexuales de clerigos con menores, Anuario Argentino de Derecho Canonico 19 (2013), s. 105-151.

Navarrete U., Transsexualismus et ordo canonicus, Periodica 86 (1997), s. 101-124.

Nowa Kowski B., Transwestytyzm a zdolność osoby do zawarcia małżeństwa, Łódzkie Studia Teologiczne 28 (2019) nr 3, s. 171-182.

Oesterle G., Welchen Einfluss hat die Homosexulität auf die Ehe?, Österreichisches Archiv für Kirchenrecht 12 (1961) s. 305-337.

Piegsa J., Człowiek - istota moralna, t. 3, Opole 2000.

PRIsco SAN José J., Nuevas normas sobre la nulidad de la ordenación sacerdotal. Texto y comentario, Revista Española de Derecho Canónico 60 (2003), s. 117-139.

RitTy C.J., Invalidity of marriage by reason of sexual anomalies, The Catholic Lawyer 10 (1964) nr 2, s. 90-108.

STANKIEwICZ A., Homoseksualizm jako przyczyna nieważności mał̇̇éstwa według najnowszej jurysprudencji rotalnej (1956-1976), Prawo Kanoniczne 22 (1976) nr 3-4, s. 179-198.

Sztychmiler R., Istotne obowiązki małżeńskie w Kodeksie Prawa Kanonicznego z 1983 roku, Roczniki Nauk Prawnych 7 (1997), s. 121-138.

Sztychmiler R., Obowiązki małżeńskie: istotne i nieistotne, Ius Matrimoniale 9 (1998) nr 3, s. 115-134.

Sztychmiler R., Problem określenia istotnych obowiązków małżeńskich, Ius Matrimoniale 7 (1996) nr 6/1, s. 59-77. 
Wesemann P., Psychiczna niezdolność do małżeństwa jako problem sq̨downictwa kościelnego, Kościół i Prawo 3 (1984), s. 79-110.

Zuanazzi G., Psicologia e psichiatria nelle cause matrimoniali canoniche, Città del Vaticano 2012.

Zuanazzi G., Psicología e psichiatria nelle cause matrimoniali canoniche, Roma 2006.

Zysкowsкa E., Rola biegłego psychiatry i psychologa w kanonicznym procesie o stwierdzenie nieważności małżeństwa na przykładzie kan. 1095 KPK, Kwartalnik Naukowy Fides et Ratio 28 (2016) nr 4, s. 297-310.

Źródła

Nauki medyczne

Diagnostic and Statistical Manual of Mental Disorders, Washington DC 1968.

\section{Opracowania}

Krueger R.B., Reed G.M., First M.B., Marais A., Kismodi E., Briken P., Proposals for Paraphilic Disorders in the International Classification of Diseases and Related Health Problems, Eleventh Revision (ICD-11), Archives of Sexual Behavior 46 (2017) nr 5, s. 1529-1545.

\section{Nota o autorze}

Kinga Szymańska - doktor nauk prawnych w zakresie prawa kanonicznego, prawnik, politolog religii, psychotraumatolog. Notariusz i audytor w Sądzie Metropolitalnym Warszawskim. Autorka publikacji z zakresu małżeńskiego prawa kanonicznego, psychiatrii i psychologii. 